\title{
Seasonal dynamics of phytoplankton in acidic and humic environment in thaw ponds of discontinuous permafrost zone
}

\author{
O. A. Pavlova ${ }^{1}$, O. S. Pokrovsky ${ }^{2 *}$, R. M. Manasypov ${ }^{3 \cdot 4}$, L. S. Shirokova ${ }^{2 \cdot 4}$ and S. N. Vorobyev ${ }^{3}$ \\ 1 Institute of Limnology RAS, 9 Sevastianova st., St. Petersburg, Russia \\ 2 GET UMR 5563 CNRS, University of Toulouse, 14 Avenue Edouard Belin, 31400 Toulouse, France \\ 3 BIO-GEO-CLIM Laboratory, Tomsk State University, Lenina 36, Tomsk, Russia \\ ${ }^{4}$ Institute of Ecological Problem of the North RAS, 23 Nab Severnoi Dviny, Arkhangelsk, Russia
}

Received 8 September 2015; Accepted 4 February 2016

\begin{abstract}
Despite the high importance of shallow thaw ponds (thermokarst lakes) of Western Siberia in both surface coverage and carbon dioxide and methane emission to the atmosphere, their planktonic component remains poorly characterized. This work reports the first results of phytoplankton analysis of thaw lakes and ponds sampled during spring flood, open water season and ice formation. The lakes, located within the discontinuous/sporadic permafrost $\left(66^{\circ} \mathrm{N}\right)$, are shallow $(0.5-1.5 \mathrm{~m}$ depth$)$, acidic $(4.0 \leq \mathrm{pH} \leq 6.1)$ and highly organic (10-40 mg. $\mathrm{L}^{-1}$ of DOC) with low concentrations of total dissolved solid (10-30 mg. $\left.\mathrm{L}^{-1}\right)$. In the plankton community of 20 lakes of variable size (from $700 \mathrm{~m}^{2}$ to $1.8 \mathrm{~km}^{2}$ ), we identified 134 taxa of algae with the dominance of green algae (33-60\% of total), cyanobacteria $(11-14 \%)$ and dinoflagellates $(7-14 \%)$. The total cell number $(N)$ ranged from 20 to 83 million cell. $L^{-1}$ and the biomass $(B)$ ranged from 0.1 to $37 \mathrm{mg}_{\text {wet. }} \mathrm{L}^{-1}$ with the dominance of green algae, Dinophyta and Charophyta Ulothrix spp., Bambusina brebissonii. A Principal Component Analysis (PCA) revealed two possible factors responsible for phytoplankton variation: dissolved inorganic carbon, positively acting on cell number and the biomass of cyanobacteria, and DOC, Si and Fe, controlling the number of diatoms and green algae. In August, there was a general increase of both $\mathrm{N}$ and $\mathrm{B}$ as $\mathrm{pH}$ increased. Colony-forming cyanobacteria and green algae with thick capsules were highly abundant during all seasons. The specific acidic and organic-rich context of the shallow thermokarst waters subjected to full freezing in winter is one of the major factors limiting both the biodiversity and the biomass of the phytoplankton in these water objects.
\end{abstract}

Key words: Phytoplankton / thaw ponds / biogeochemistry / season / adaptation

\section{Introduction}

Shallow thaw (thermokarst) lakes of western and Northern Siberia occupying the territory larger than 1 million $\mathrm{km}^{2}$, ranging north from $60^{\circ}$ to the Arctic coast, are among the most dynamic and vulnerable pristine aquatic systems in the world. The importance of these water bodies in the overall regulation of the $\mathrm{CO}_{2}$ exchange with the atmosphere stems from their high coverage of the land's surface (30-80\% of the watershed area), short life cycle (decades to several hundred years) and essentially heterotrophic status with the dominance of microbial respiration of allochthonous DOM over the primary productivity. The overall respiration of $\mathrm{CO}_{2}$ by heterotrophic aerobic bacterioplankton normalized to the area covered by thermokarst lakes is comparable with the total carbon

\footnotetext{
*Corresponding author: oleg@get.obs-mip.fr
}

export from the land to the Arctic Ocean by Siberian rivers (Shirokova et al., 2009, 2013; Pokrovsky et al., 2014). The main particularities of the thermokarst lakes of Western Siberia are as follows (Manasypov et al., 2014, 2015): (i) high concentration of dissolved organic carbon (DOC) of soil (peat) origin ranging from 10 to $50 \mathrm{mg} . \mathrm{L}^{-1}$ depending on the lake size and the growth stage and a factor of ten lower dissolved inorganic carbon (DIC) concentration, (ii) acidic environments due to peat $/$ moss leachate products $(3 \leq \mathrm{pH} \leq 6)$ and (iii) full freezing of these shallow $(0.5-1.0 \mathrm{~m})$ water bodies during winter. The combination of these environmental factors render these highly abundant lakes unique from both the hydrobiological and hydrochemical point of view compared to other, relatively well-studied lakes of Scandinavia (Hay et al., 2000; Forsström et al., 2005, 2007; Rautio et al., 2011), NW Russia (Getsen, 1985; Trifonova, 1998) and Canada and Alaska (Sheath and Steinman, 1982; Sheath, 1986; 


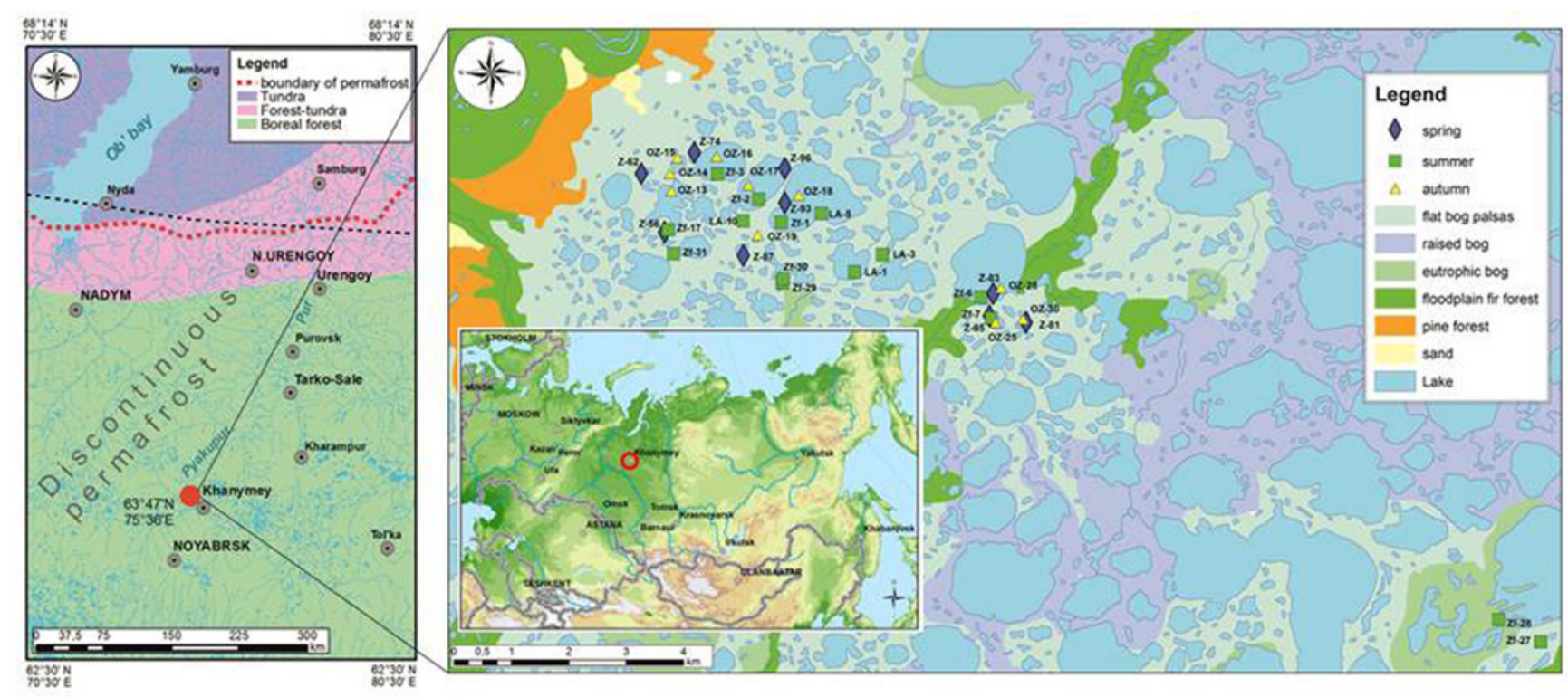

Fig. 1. Map of the study site. The lakes were sampled from the middle at $0.2-0.5 \mathrm{~m}$ depth. Zf series, June 2013; Z and LA series, August 2013 and 2014; OZ series, October 2013. Detailed hydrochemical information on sampled lakes is listed in Table ESM-1 (online material).

Douglas and Small, 1994, 1995; Milot-Roy and Vincent, 1994; Sheath et al., 1996; Tang and Vincent, 1999;Vincent, 2000; Levine and Whalen, 2001). Typically, phytoplankton represents $<2 \%$ of total photosynthetic biomass in the Arctic ponds and shallow lakes of North America (Bonilla et al., 2005). In terms of the taxon number, the following order of abundance has been observed in Canadian lakes and rivers: diatoms $>$ green algae $>$ cyanobacteria (Sheath and Steinman, 1982), although the diatoms were almost absent in temporary pools (Moore, 1978). However, because many thermokarst water bodies in Western Siberia are highly shallow and often ephemeral (Pokrovsky et al., 2013), acidic and humic, it is difficult to extrapolate the results of other arctic and subarctic water objects to Western Siberia.

To the best of our knowledge, no information concerning the phytoplankton communities of Western Siberia thermokarst lakes is available to date. Therefore, the main objective of the present study was to assess the phytoplankton diversity and abundance in the pilot site of thermokarst lake development in Western Siberia. As a working hypothesis, we assume that, given shallow, acidic and humic context of lakes during open water period, the dominant primary producers will be benthic, acid-resistant green algae rather than cyanobacteria and diatoms. Because the lakes freeze solid in winter, the main adaptation mechanism of the phytoplankton may be formation of multicellular colonies with thick capsules. Toward testing these adaptation strategies, the specific aims of this study were the following: (i) identify the dominant taxa in terms of cell number and biomass, (ii) reveal the effect of season on phytoplankton biomass and biodiversity in lakes of wide range of size and chemical composition and (iii) test the effect of physical (area) and chemical $(\mathrm{pH}$, dissolved organic and inorganic carbon, major and trace element) parameters on the lake phytoplankton abundance. Addressing these issues will help to predict the diversity and biomass of primary producers in poorly studied thaw lakes and evaluate their capacity to remove $\mathrm{CO}_{2}$ from the atmosphere.

\section{Study site and methods}

The study site is located in the central part of Western Siberia $\left(63.5^{\circ} \mathrm{N}, 75.4^{\circ} \mathrm{E}\right.$, Nojabrsk region). The field of thermokarst lake development lies on a palsa peat bog of discontinuous permafrost within the northern taiga geographical sub-zone over Late Pleistocene sand and clay deposits that are covered by a layer of peat 1 to $2 \mathrm{~m}$ thick (Fig. 1). All the lakes in this study were located at watershed divides between adjacent rivers. The water bodies ranged from $200 \mathrm{~m}$ to several $\mathrm{km}$ in diameter and had a similar depth of $0.75 \pm 0.25 \mathrm{~m}$ under normal precipitation/evaporation conditions during summer baseflow. The morphology, hydrology and the water balance of thermokarst lakes have been extensively studied in June, August, and October 2013 and February 2014 (Manasypov et al., 2015). Based on the total dissolved nutrient concentration, the lakes can be considered as oligotrophic and weakly mesotrophic. Highly acidic $(3 \leq \mathrm{pH} \leq 4)$, small water bodies $\left(<1000 \mathrm{~m}^{2}\right)$ located within the palsa peat bog often contain $>30 \mathrm{mg} . \mathrm{L}^{-1}$ of DOC and can be considered as dystrophic. During open water seasons, all shallow water bodies were fully oxygenated $\left(100 \pm 10 \% \mathrm{O}_{2}\right.$ saturation); however, $30-50 \% \mathrm{O}_{2}$ depletion was observed in the bottom layer of the water column in October, at the beginning of the winter (Manasypov et al., 2015). Many thaw ponds sampled in August were already frozen solid in October, whereas the 
ponds existing in June were dry in August. Given low depth of sampled ponds, their surface areas ranged significantly during the year; the values used for results interpretation in this study were measured on-site during each period of sampling. Because of severe sampling conditions in the north of Western Siberia, not all lakes could be visited during all three seasons. The access to the August-period lakes was limited during high flood in June and over $20 \mathrm{~cm}$ of snow in October.

In this study, 20 lakes have been sampled during three main hydrological seasons in 2013-2014, excluding the winter period when the lakes freeze solid (see Table ESM-1, online material). Normally, two to three samples per lake were collected; however, no significant variation (at $P<0.05$ ) of hydrochemical parameters was observed across the lake area and between surface and bottom layer. An important peculiarity of Western Siberia thaw ponds is high homogeneity of their physical and chemical parameters, across a wide range of pond size, typically $>1000 \mathrm{~m}^{2}$ surface area. Based on rigorous statistics during different periods of the year, Manasypov et al. (2015) demonstrated that the differences between lakes of different size (within the range $10^{4}-10^{6} \mathrm{~m}^{2}$ ) are much smaller than the differences between seasons. As a result, two ponds of similar size located within the same watershed can be considered identical at the date of sampling, since they are physically and chemically indistinguishable. For this reason, although only three exactly the same ponds were sampled during each season, the overall dataset consisting in six ponds in June, eight in August and six in October can be considered representative and sufficient for assessing the temporal variability of thaw pond seasonal dynamics. Note that such a homogeneous distribution of estern Siberia thaw ponds in discontinuous permafrost zone of the watershed divide (palsa plateau) contrasts thermokarst lakes of the Eastern Canadian sub-Arctic, Mackenzie Delta region, and Canadian High Arctic lakes that are regulated by local landscape features, such as the extent of permafrost thaw and disturbances linked to sediment loading (Kokelj et al., 2005, 2009; Dugan et al., 2012; Comte et al., 2015).

In our sampling scheme, the beginning of June, right after the massive ice break corresponded to "biological spring," the beginning of August exhibited the highest water temperatures and thus corresponded to biological "summer" and the beginning of October corresponded to the beginning of the ice formation $(10-20 \mathrm{~cm})$ and can be considered as biological "autumn." Two 500-mL bottles of lake water was collected from the central part of the lake (or the deepest part if it was close to the border) using a rubber boat, from the depth of $20 \pm 10 \mathrm{~cm}$ and immediately fixed with formalin (final concentration $4 \%$ ) and Lugol's solution. The lake water samples were stored in the refrigerator, concentrated by sedimentation and counted in a Najotte chamber of $0.05 \mathrm{~mL}$ volume (Guseva, 1959; Trifonova and Petrova, 1994; Trifonova, 1998). The biomass was determined as algal volume for each lake and converted to wet weight assuming a density of $1 \mathrm{~g} . \mathrm{cm}^{-3}$ after approximating the geometry of the cell (Makarova and Pichkily, 1970). The microscopes AxioLab A1 and Axiovert CFL-40 (Carl Zeiss) were used to assess the cell number and morphology. The phytoplankton diversity was evaluated using the Shannon-Weaver's index $(H)$ and Pielou's index based on the biomass (Odum, 1971). The saprobity state of the water bodies was evaluated using the indices of Pantle and Bukk modified according to Sládecek (1973) and Barinova et al. (2006).

The hydrochemical parameters were measured on-site ( $\mathrm{pH}, T$, specific conductivity and $\mathrm{O}_{2}$ concentration) and in the laboratory. Major anion concentrations $\left(\mathrm{Cl}^{-}\right.$and $\mathrm{SO}_{4}^{2-}$ ) were measured by ion chromatography (HPLC, Dionex ICS-2000) with an uncertainty of $2 \%$. DOC was analyzed using a Carbon Total Analyzer (Shimadzu TOC 6000 ) with an uncertainty lower than $3 \%$. Major and trace elements were determined with an ICP-MS Agilent ce 7500 , routinely used in our laboratory for the analysis of samples from boreal organic-rich lakes (cf. Pokrovsky et al., 2013). Indium and rhenium were used as external standards. The international geostandard SLRS-5 (Riverine Water Reference Material for Trace Metals certified by the National Research Council of Canada) was used to check the accuracy and reproducibility of each analysis (Yeghicheyan et al., 2013). We obtained good agreement between replicate measurements of SLRS and certified values (relative difference $<10 \%$ SD for repeated measurements), except for $\mathrm{B}$ and $\mathrm{P}(30 \%)$.

The data on the taxon numbers were analyzed with best fit functions based on the Pearson correlation and one-way ANOVA with the STATISTICA version 8 software (StatSoft Inc., Tulsa, OK). Regressions and power functions were used to examine the relationships among the cell number, the biomass, the $\mathrm{pH}$ and DOC concentration in the lake water. The correlation coefficients allowed elucidating the relationships between the DOC, DIC, $\mathrm{pH}$ and quantitative parameters of the phytoplankton within the same season and between measured parameters over the full dataset. A criterion for a significant correlation between chemical and biological parameters was that the Pearson coefficients were higher than $0.5(R \geq 0.5$ at $P<0.05)$. The ANOVA method was used to test the differences in the biomass and cell number among different lake size, chemical composition and seasons. The ANOVA test was performed with a one-way analysis of variance using Dunn's method due to the different number of sampled lake for each season (SigmaPlot version 11.0/Systat Software, Inc). In this method, a value of $P<0.05$ indicates that the differences in the median values are important and are statistically significant. Further statistical analyses ( $H$-criterion of KruskalWallis and Mann-Whitney $U$ test) used in assessing the differences or similarities in hydrochemical and hydrobiological parameters between lakes of different size sampled during different seasons is described in previous work on hydrochemistry of Western Siberia thaw ponds (Manasypov et al., 2015).

Principal component analysis (PCA) was used for the ensemble of sampled lakes and for each season individually, to reduce the number of variables and to detect the 
Table 1. Dominant phytoplankton species in thermokarst lakes of Western Siberia. The authors' names of species are given in Table ESM-2, online material.

\begin{tabular}{|c|c|c|}
\hline Season & Dominants in cell number & Dominants in biomass \\
\hline Spring (1-5 June) & $\begin{array}{l}\text { Aphanocapsa delicatissima W. et G.S. West } \\
\text { Batrachospermum sp. } \\
\text { Chrysophyceae spp. } \\
\text { Planktolyngbya limnetica (Lemm.) Kom.-Legn. et Cronb. } \\
\text { Uroglenopsis americana Reverdin }\end{array}$ & $\begin{array}{l}\text { Bambusina brebisonii } \\
\text { Chrysophyceae spp. } \\
\text { Gymnodinium spp. } \\
\text { Peridinium spp. } \\
\text { Stephanodiscus spp. } \\
\text { Tabellaria flocculosa } \\
\text { U. americana } \\
\text { Ulothrix spp. }\end{array}$ \\
\hline $\begin{array}{l}\text { Summer } \\
\text { (10-15 August) }\end{array}$ & $\begin{array}{l}\text { Aphanizomenon gracile (Lemm.) Lemm. } \\
\text { B. brebisonii } \\
\text { Desmidium schwartzii } \\
\text { Merismopedia tenuissima Lemm. } \\
\text { Oscillatoria sp. } \\
\text { T. flocculosa } \\
\text { Tetrastrum triangulare (Chod.) Kom. }\end{array}$ & $\begin{array}{l}\text { B. brebisonii } \\
\text { Botryococcus braunii } \\
\text { Ceratium cornutum (Ehrb.) Clapar. et Lachm. } \\
\text { D. schwartzii } \\
\text { Gymnodinium spp. } \\
\text { Peridinium cinctum (Müll.) Ehrb. } \\
\text { T. flocculosa }\end{array}$ \\
\hline $\begin{array}{l}\text { Autumn } \\
\text { (15-20 October) }\end{array}$ & $\begin{array}{l}\text { A. delicatissima } \\
\text { Asterionella formosa Hass. } \\
\text { Bambusina brebisonii } \\
\text { Botryococcus braunii } \\
\text { Chroomonas acuta } \text { Uterm. } \\
\text { Cryptomonas spp. } \\
\text { Dinobryon spp. }\end{array}$ & $\begin{array}{l}\text { Asterionella Formosa } \\
\text { Bambusina brebisonii } \\
\text { B. braunii } \\
\text { Chroomonas acuta } \\
\text { Peridinium spp. }\end{array}$ \\
\hline
\end{tabular}

structure in the relationships between the physical (surface area), chemical ( $\mathrm{pH}, \mathrm{DOC}, \mathrm{DIC}$, major cation and trace metals) and biological (biomass, cell number of various taxa and total cell number) elements. The data consisted of 20 lake water samples grouped into three distinct seasons (spring, summer and autumn). Statistical PCA analyses were applied in order to derive a distinctive view of the influence of various parameters, notably the hydrochemistry of the lake water, on the phytoplankton biodiversity, cell number and biomass. For this, the STATISTICA package (http://www.statsoft.com) was used to reveal a factorial structure (see an example for 130 thaw lake major and trace elements seasonal distribution in Manasypov et al. (2015).

\section{Results}

\section{Biodiversity of the phytoplankton}

The map of the sampling site is presented in Figure 1 and the list of sampled lakes together with main hydrochemical parameters is given in Table ESM-1 of the Electronic Supporting Material. The dominant species during each period, representing more than $10 \%$ of total species number, are listed in Table 1 and the mean biomass and cell number together with statistical criteria (standard deviation, 2nd and 3rd quartiles) of the main group of algae are illustrated in Figure 2.

Based on three sampling campaigns conducted in 20 lakes, 134 taxa of algae species (without detailed analysis of diatom) were found. In June, August and
October, we identified 50, 106 and 18 taxa, respectively. The highest biodiversity was recorded among Charophyta (Conjugatophyceae comprising 49 taxa representing from 6 to $43 \%$ of total encountered forms), green algae (27 taxa corresponding to $18-28 \%$ of total forms), cyanobacteria (18 taxa corresponding to $11-14 \%$ forms) and Dinophyta (11 taxa of $7-14 \%$ forms). Although the sampling was always performed from the water column, notable components of the identified algae were represented by benthic and periphytic forms of the classes Conjugatophyceae, Chlorophyceae, Bacillariophyceae, Fragillariophyceae, Cyanophyceae, Florideophyceae (Rhodophyta) and others. The list of strictly phytoplankton, benthic and phytoplankton-benthic species encountered in Western Siberia thaw ponds is given in Table ESM-2. The majority of the filamentous forms were determined with a resolution of genus, because for precise identification, one needed colonies at the conjugation (reproduction) stage, which were not observed. A generic group of Flagellatawas distinguished that comprised flagellic and coccoid forms of algae from diverse taxa and size fractions that were poorly identified after fixation.

There was little difference in the taxon distributions between the spring and autumn periods, with an increase of golden algae and cryptomonads in October relative to June. The total number of taxa ranged from 11 to 22 and from 2 to 13 in spring and autumn, respectively. The most abundant species during these periods were Tabellaria flocculosa (Roth) Kütz., Chroomonas acuta Uterm., species genera Cryptomonas, Gymnodinium, Chrysococcus, Dinobryon and Uroglenopsis. 

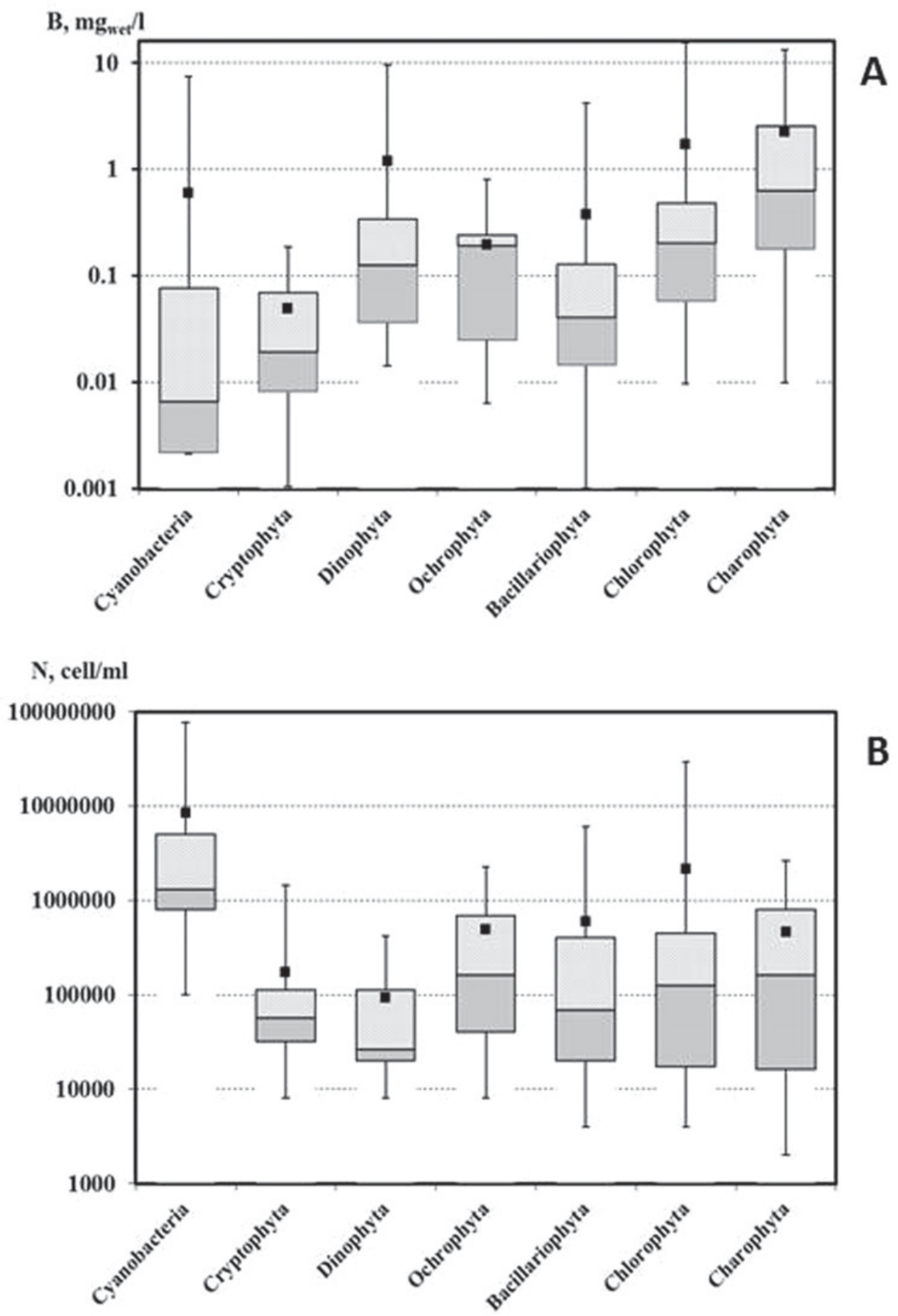

Fig. 2. Season-averaged biomass (A) and cell number (B) of main phytoplankton taxa. The average with standard deviation is shown by black squares with error bars, the second and the third quartiles are shown by dark-gray and light-gray rectangles, respectively.

In summer, the number of algae taxa ranged from 4 to 45. Green algae dominated the population $(61 \%)$, with smaller proportion of cyanobacteria and diatoms (15 and $9 \%$, respectively). The maximum biodiversity, more than 80 taxa, was recorded in the small lake A-2, which also had the highest $\mathrm{pH}$ recorded among all sampled sites (6.10). This was especially true for the case of Desmidiales, comprising 48 species of 18 genera making it $63 \%$ of total 76 of Chlorophyta and $36 \%$ of total 134 species. Based on quantitative estimation, genera Closterium comparised eight taxons and genera Cosmarium, Euastrum and Micrasterias comprised from 5 to 6 taxons. The maximal diversity of Desmidiales (31 of 72 taxons) was also observed in August sample A-2. Here, the dominants were Closterium (seven taxons), Cosmarium, Euastrum and Micrasterias (four to five taxons). Other summer samples with lower $\mathrm{pH}$ (5.5-5.9) demonstrated significantly smaller number of Desmidiales taxons, without clear dependence on $\mathrm{pH}$ (Table 2).

Overall, the phytoplankton was represented by typical acidophilic forms, Bambusina brebissonii Kutz., Desmidium schwartzii Ag.; the dominant species genera were Micrasterias, Closterium, Cosmarium, Euastrum, Staurastrum, Staurodesmus. In almost all the lakes, 
Table 2. Taxa distribution in the lakes during the three observation seasons.

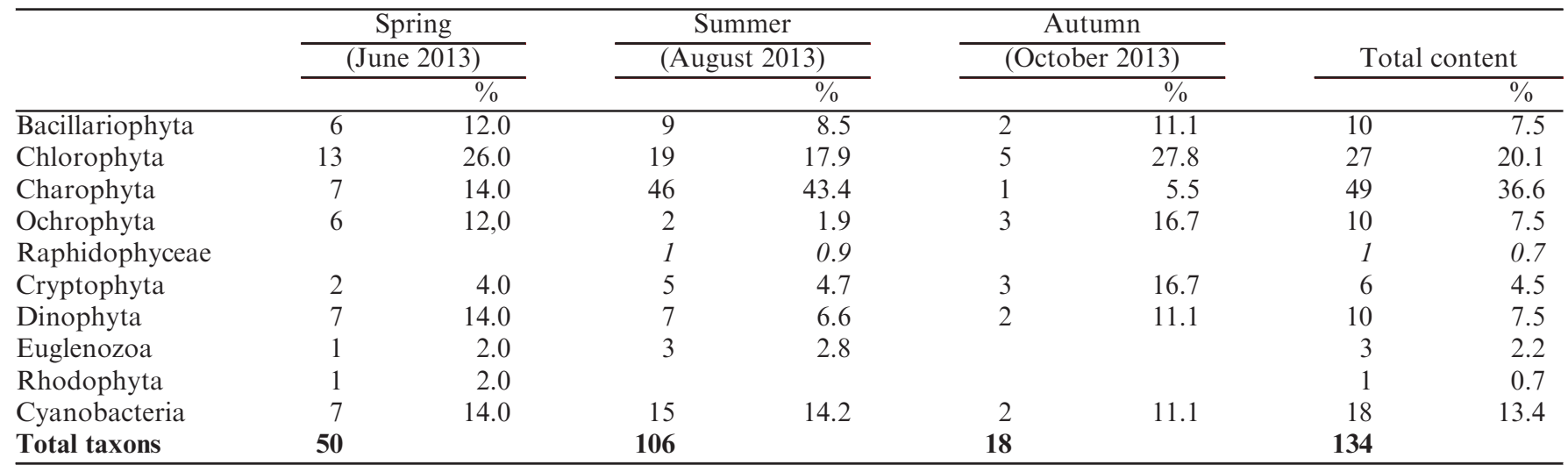

Botryococcus braunii Kütz., T. flocculosa, species genera Gymnodinium, Cryptomonas, Chlamydomonas, pennate diatoms of genera Navicula, Pinnularia, Fragilaria were detected. The exact determination of golden algae (Chrysophyta) from June's sampling (J series) was difficult due to the lack of flagella used as main diagnostic feature. There were frequent occurrences of Chrysococcus, which most likely combined species Ochromonas or Chromulina. Typical examples of colony-forming cyanobacteria and green algae of Western Siberia thaw ponds are shown in Figures ESM-1 and 2, respectively (online material).

\section{Quantitative parameters of the phytoplankton}

The PCA analysis revealed certain structure in the distribution of (physical (surface area), chemical (pH, DOC, DIC, major and trace elements) and biological (biomass, cell number of various taxa and total cell number) variables as shown in Figure 3(A) and (B) for all seasons and August, respectively. The first factor is DIC, positively acting on total cell number, the biomass and the number of Cyanobacteria, Euglenozoa, and Charophyta. The second factor is DOC, determining the number of diatoms and green algae. It is important to note that, in addition to DOC, the second factor included $\mathrm{Fe}$ and $\mathrm{Si}, \mathrm{K}$, $\mathrm{Al}$ and $\mathrm{Cl}$, both for August series and all-seasons treatment. Finally, the number of Cryptophyta, Dinophyta, Ochrophyta, Rhodophyta and Flagellata seem to be weakly linked to any physical or hydrochemical parameter of the lake.

In the lakes sampled in June ( $\mathrm{J}$ series), the phytoplankton number and biomass ranged from 1 to 6.9 million cell. $\mathrm{L}^{-1}$ and from 0.28 to $12.7 \mathrm{mg}_{\text {wet }} . \mathrm{L}^{-1}$, respectively. The maximal numbers were encountered in lake J-5, which was strongly diluted by spring flood water (snow thaw) as it exhibited only $5.5 \mathrm{mg}^{-\mathrm{L}^{-1}}$ DOC (Table ESM-1) and quite low specific conductivity $\left(7 \mu \mathrm{S} \mathrm{cm}{ }^{-1}\right.$ compared with the typical 20-30 $\mu \mathrm{S} . \mathrm{cm}^{-1}$, Manasypov et al., 2015). The biomass in the lakes of spring sampling was dominated by golden algae, which represented more than $50 \%$ in lake J-3, the lake that exhibited the highest DOC concentration and lowest $\mathrm{pH}$. In lakes $\mathrm{J}-5$ and $\mathrm{J}-6$, green algae Ulothrix spp. (U. cf. zonata (Weber et Mohr) Kütz.) and charales $B$. brebissonii dominated the planktonic biomass constituting up to 80 and $20 \%$, respectively. Red algae (Rhodophyta) were encountered only in lake J-5 where Batrachospermum sp. accounted for $\sim 9 \%$ of the biomass. The nanoplanctonic cyanobacteria, such as chroococcales Aphanocapsa delicatissima W. et G.S. West and species of genusMerismopedia were also detected in spring, dominating the total cell number in certain samples.

The highest biomass and cell number were recorded in small $\left(<32000 \mathrm{~m}^{2}\right.$ area $)$ lakes sampled in August (A series), with the maximal values of 83 million cell. $\mathrm{L}^{-1}$ and $37 \mathrm{mg}_{\text {wet }} . \mathrm{L}^{-1}$, respectively (Fig. 4, Table ESM-1). The dominant components of the biomass were charophytes (essentially desmids) and green algae constituting both up to $35 \%$ - Chlorococcales B. braunii $(\leq 35 \%)$ and filamentous $B$. brebissonii. Additionally, cyanobacteria Oscillatoria tenuis was frequently observed. In the spring samples from early June (series $\mathbf{J}$ ), the biomass dominants were golden algae $(\leq 67 \%$ in sample $J-4)$, and Dinophyta (more than $50 \%, \mathrm{~J}-3$ ). The following green algae dominated the biomass: desmids Desmidium swartzii, up to $73 \%$ in A-1 and B. brebissonii, up to $83 \%$ in A-3; Chlorococcales $B$. braunii, up to $35 \%$ in A-2; diatoms T. flocculosa, up to $83 \%$ in A-4; Dinophyta Ceratium cornutum (Ehrb.) Clapar. et Lachm., and Gymnodinium spp., up to $71 \%$ in A-5; and in a lesser degree, cyanobacteria $O$. tenuis, species of genus Aphanizomenon, up to $20 \%$ in A-2.

The minimal development of the phytoplankton was observed in October, after the first ice cover formation (series O). The total cell number ranged from 0.08 to 5.3 million cell. $\mathrm{L}^{-1}$, and the biomass ranged from 0.01 to $0.64 \mathrm{mg}_{\text {wet }} \cdot \mathrm{L}^{-1}$. The lakes O-5 and O-6 exhibited the highest biomass. The biodiversity was quite low, less than 11 taxa (sample O-6) and we typically found three to five different taxa. During autumn period, up to $98 \%$ of the total biomass was represented by charophytes and green algae, with an especially high contribution of B. brebissonii (up to $97 \%$ ) and B. braunii (up to $87 \%$ ). Concerning cell number, the cryptomonads (C. acuta Uterm.) and golden 

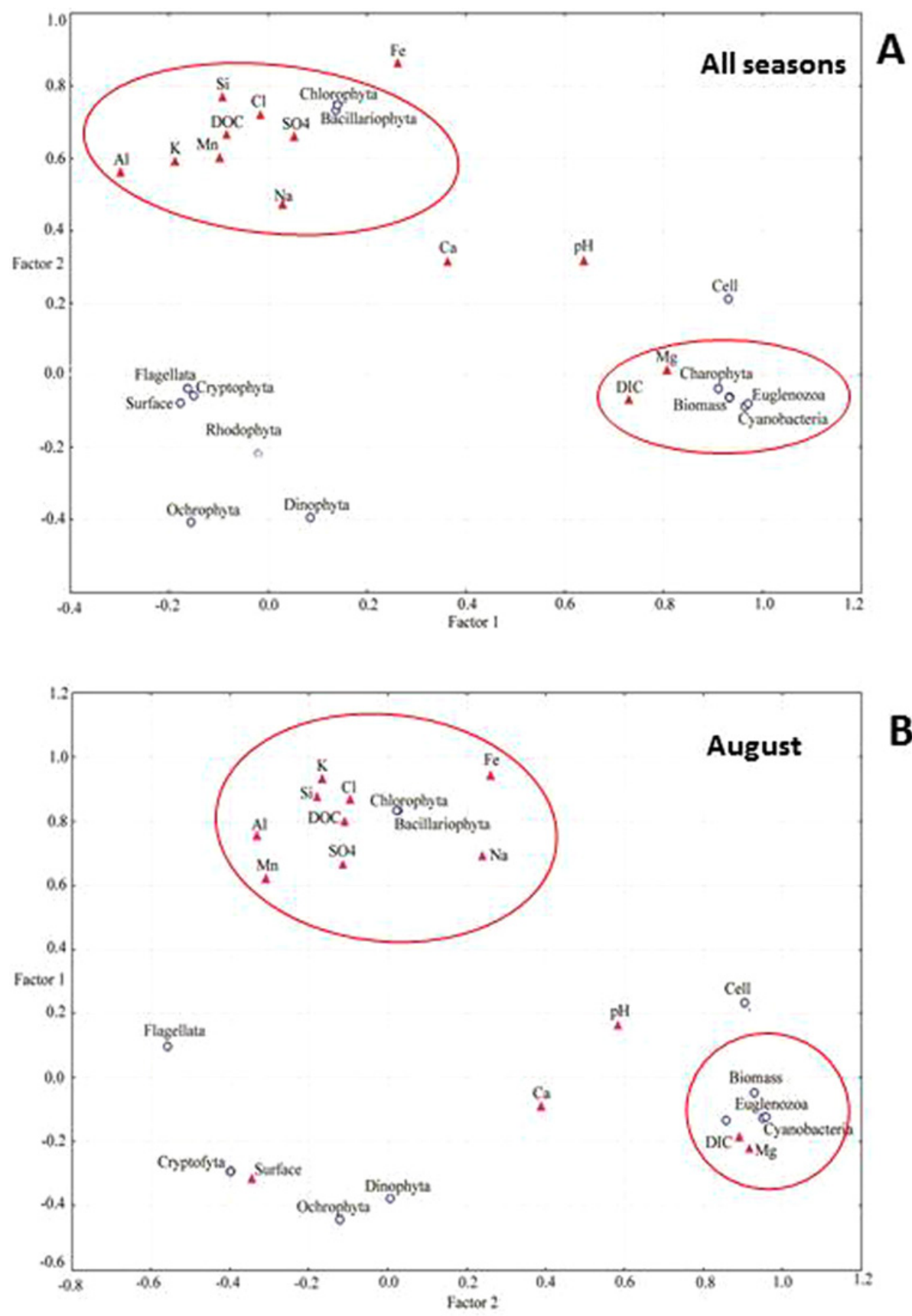

Fig. 3. Results of PCA analysis of hydrochemical and phytoplankton parameters of thaw lakes. The two main factors are DIC, acting on N, B, Cyanobacteria, Euglenozoa and Charophyta, and DOC-Si-Fe, determining the number of diatoms and green algae.

algae (Dinobryon divergens Imhof) were the dominant species during this period.

The Shannon's diversity index $(H)$ and Pielou's evenness index of equitability $(P)$ were used to characterize the phytoplankton community. In June, the index of biodiversity $(H)$ varied from 1.26 to 3.08 , whereas the Pielou's index of equitability in the phytoplankton community ranged from 0.28 to 0.86 . These indexes ranged from 1.09 to 3.72 and from 0.27 to 0.61 , respectively, in August and from 0.27 to 2.78 and 0.12 to 0.96 , respectively, in October (Fig. 4). In most lakes, reverse relationships between the parameters of phytoplankton diversity and biomass were observed (at $P<0.05$ confidence level).

Results of saprobity analysis demonstrated that the number of cells was dominated by oligo-, oligo- $\beta$ and $\beta$-oligo-mesosaprophic microorganisms. This finding suggests the degree of organic "pollution" in the studied lakes as $\beta$-oligo-meso-saprophic. Note, however, that this definition is highly conventional because part of the encountered taxa does not possess saprophic valency and is not used for index calculation or was not identified until the species level. 


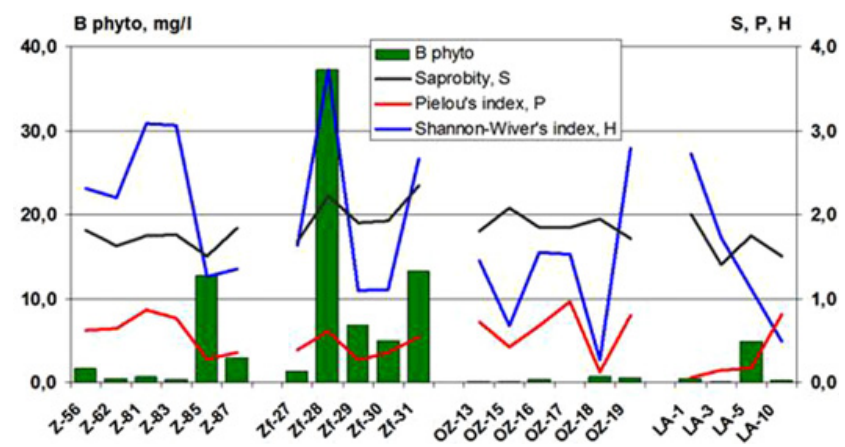

Fig. 4. Evolution of algae biomass (B phyto, mg. $\mathrm{L}^{-1}$ ) and biodiversity indices Shannon $(\mathrm{H})$ and Pielou $(\mathrm{P})$ and Saprobity index (S) in the thermokarst lakes of Western Siberia during different seasons. The numbers of lakes correspond to those given in Table ESM-1 of the Supplement.
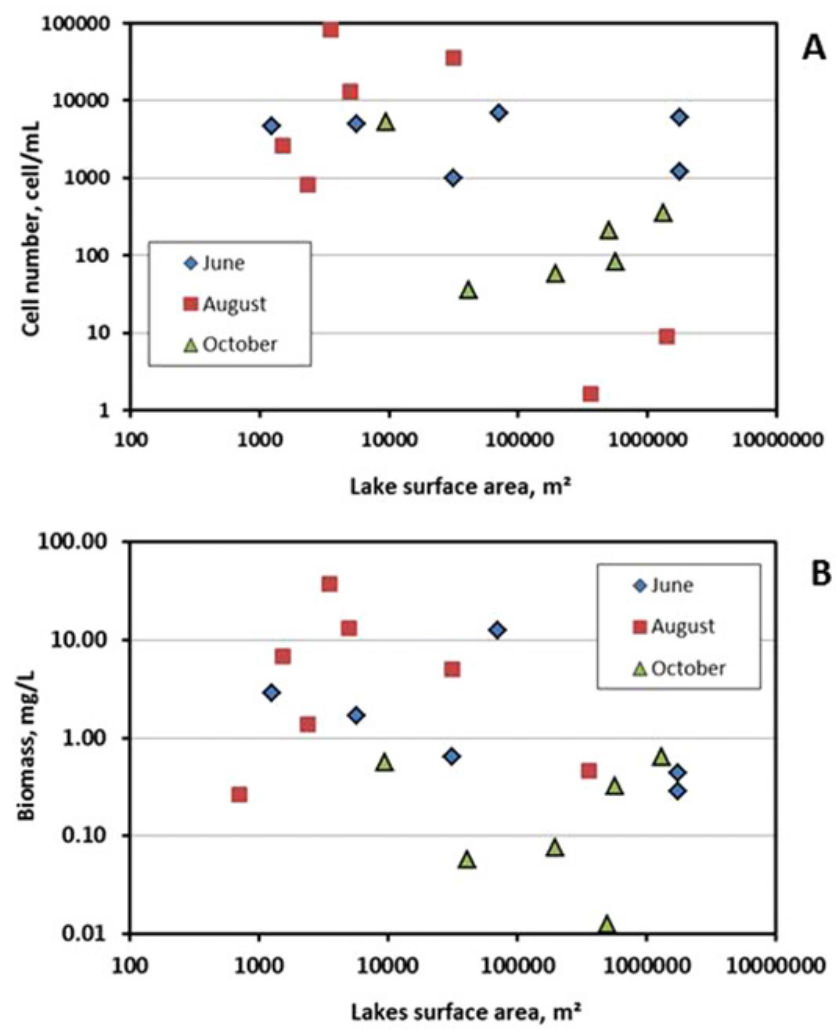

Fig. 5. Biomass (A) and cell number (B) concentration as a function of the lake size in Western Siberia during June (diamonds), August (squares) and October (triangles).

Considering all seasons together, the cell number and biomass decreased with the increase of the lake surface area (Fig. 5(A) and (B), respectively). Although this exponential trend is statistically significant $(P<0.05)$, it can be partially biased by the fact that the largest lakes have been sampled in June and October, the periods of minimal phytoplankton development, whereas the small lakes sampled in August 2014 yielded notably low biomass. There was a general decrease of the total cell number and biomass with the decrease of lake water $\mathrm{pH}$ illustrated for

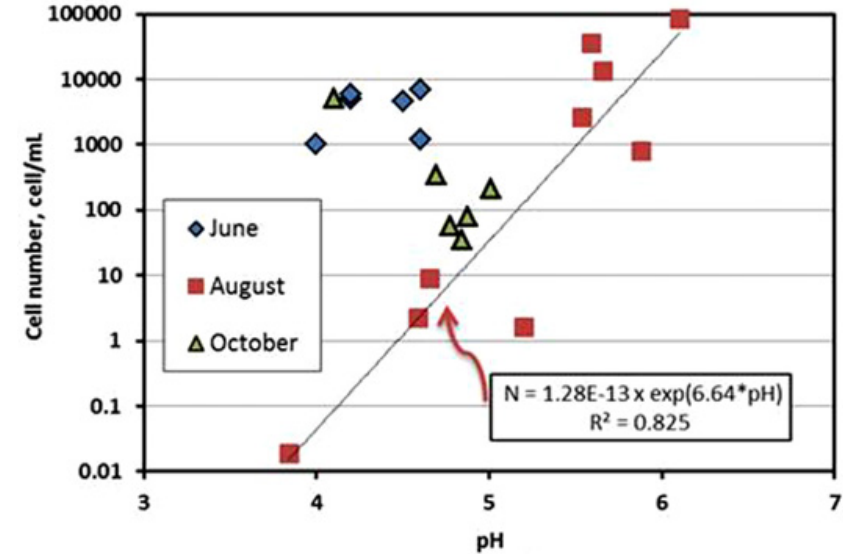

Fig. 6. A plot of cell number as a function of $\mathrm{pH}$ in the thermokarst lakes of Western Siberia, as sampled during different seasons. Considering all seasons together, the link is statistically significant at $P<0.05$. Note the lack of $\mathrm{pH}$ control on the cell number in June and significant correlation in August $\left(R^{2}=0.83\right.$, see text).

$\mathrm{N}-\mathrm{pH}$ plot in Figure 6. There was a lack of $\mathrm{pH}$ control in June and a negative relationship in October, but the positive trend was pronounced in August. During this period, the dependence between the cell biomass and $\mathrm{pH}$ was much less pronounced that that between the cell number and $\mathrm{pH}\left(R^{2}=0.50\right.$ and 0.83 , respectively $)$.

\section{Discussion}

\section{General features of cell number and biodiversity evolution as a function of season and lake size}

An overview of the collected samples confirms their similar landscape and environmental context with distinct differences between the three seasons. The acidic environment of thaw lakes is confirmed by the high variability of charales algae - desmids (species of genera Micrasterias, Pleurotaenium, Staurastrum, Cosmarium, Euastrum, Penium and others). These species are typical for low $\mathrm{pH}$ boreal waters (Kosinskaya, 1960). The prevalence of eukaryotic over prokaryotic phytoplankton was often reported in shallow eutrophic lakes (Craig, 1987; Mozés et al., 2006), in boreal humic lakes (Jasser and Arvola, 2003), and in acidic dystrophic lakes (Stockner and Shortreed, 1991). It is known that the relative role of eukaryotic plankton increases with the degree of light extinction (Pick and Agbeti, 1991). This is especially true for shallow, DOM-rich humic thaw ponds, exposed to significant solar radiation during the Arctic summer. One of the most important dominants among the charales microalgae (desmids) of thermokarst lakes is B. brebissonii, typical for oligotrophic acidic low land ponds (Coesèl and Meesters, 2007). Despite the sampling of the upper part of the water column in the middle of the lake, the major part of the dominant microorganisms was represented by benthic forms (genera filamentous green algae 
Ulothrix and Oedogonium, thalloid alga Zygnema and others). The high abundance of periphytic phototrophic microorganisms in Western Siberia thermokarst ponds is in agreement with the dominance of primary productivity by the benthic microbial mats in subarctic and arctic ponds of Canada (Rautio et al., 2011).

The increase of $H$ and $P$ indices usually was observed during the decrease of the phytoplankton biomass (Fig. 4). This strongly suggests the increase of indefiniteness and homogeneity of the community structure. The maximal value of the Shannon's index was recorded in summer in a relatively small lake (3500 $\mathrm{m}^{2}$ surface area) A-2, consistent with the high biodiversity and comparable contribution of all dominant species to the overall algal biomass. We do not have a straightforward explanation for why lake A-2, having the highest recorded $\mathrm{pH}$ (6.1) and DIC $\left(1.25 \mathrm{mg} . \mathrm{L}^{-1}\right)$, also exhibited the highest biomass and cell number. It is possible that the intensive peat leaching at the lake border could liberate significant amounts of nutrients and cause an algal bloom. Such a mechanism is indirectly supported by the elevated $\mathrm{Ca}$ and $\mathrm{Mg}$ concentration in lake A-2 (Manasypov et al., 2015). Alternatively, the source of major ions and DIC could be ground water feeding or lake macrophyte degradation. Regardless of the exact source of nutrients necessary for the enhanced phytoplankton development in this lake, the biomass of $37 \mathrm{mg}_{\text {wet }} . \mathrm{L}^{-1}$ signifies almost eutrophic conditions, comparable with those of non-thermokarst lakes of the European Russian boreal zone (Trifonova, 1998).

In accord with these results, the PCA analysis revealed the important role of DIC as a first factor control the cyanobacterial biomass and cell number. The second factor comprised $\mathrm{DOC}, \mathrm{Si}, \mathrm{Fe}, \mathrm{Al}, \mathrm{K}$ and $\mathrm{Cl}$ (Fig. 3). Whereas Si can be considered as a macro-nutrient for diatoms, Fe can act as micro-nutrient for phytoplankton in arctic lakes, as it was suggested for Alaskan Arctic foothill lakes (Levine and Whalen, 2001). Al may follow DOC being present as organic complexes (Pokrovsky et al., 2011), and $\mathrm{K}$ may reflect the interaction with clays or release from macrophytes. The role of $\mathrm{Cl}$ in control of phytoplankton is unclear; however, it may correspond to groundwater discharge, marking the concomitant mobilization of $\mathrm{Fe}, \mathrm{Al}$ and $\mathrm{K}$.

The general trends of cell number and biomass decrease with the surface area increase (Fig. 5) are remarkable and consistent with results on biogeochemical and microbiological view of Western Siberia thermokarst lake evolution (cf., Shirokova et al., 2009, 2013; Audry et al., 2011; Pokrovsky et al., 2011). From previous studies in this region, it follows that during lake maturation, from actively growing small $\left(100-1000 \mathrm{~m}^{2}\right)$ thaw water bodies to large, stable lakes $\left(n \times 10^{4}-n \times 10^{6} \mathrm{~m}^{2}\right)$, there is a decrease of DOC, salt content, and, presumably, nutrients. This decrease is accompanied by a decrease in the abundance of heterotrophic bacterioplankton and the impoverishment of the biotic activity (Shirokova et al., 2013), also detectable for both biomass and cell number of the phytoplankton, as reported in this study. Another important result is the almost full disappearance of biomass-, or cell number - surface area trend in June $(P>0.05)$, during spring flood, when the hydrochemical difference between the lakes of different size becomes minimal (Manasypov et al., 2015).

Interestingly, the range of phytoplankton biomass in the thermokarst lakes during summer $\left(1-10 \mathrm{mg}_{\mathrm{wet}} \cdot \mathrm{L}^{-1}\right)$, together with the assumption of doubling the cell population each 2 days (Shirokova et al., 2009) and the wet:dry ratio of $10: 1$, yield the primary productivity in the water column ranging from 0.025 to $0.25 \mathrm{mg} \mathrm{C} \mathrm{L}^{-1}$.day ${ }^{-1}$, which is significantly lower than the heterotrophic bacterioplankton respiration $\left(\sim 0.3 \mathrm{mg} \mathrm{C} \mathrm{L}^{-1}\right.$. day ${ }^{-1}$, Shirokova et al., 2013). The measured water column primary productivity in the majority of the thermokarst lakes of Western Siberia discontinuous permafrost zone was below $0.03 \mathrm{mg} \mathrm{C} \mathrm{L}{ }^{-1}$.day ${ }^{-1}$ (Shirokova et al., 2013). This finding confirms the net heterotrophic status of these lakes and the dominance of $\mathrm{CO}_{2}$ emission due to heterotrophic mineralization of allochthonous dissolved organic matter. Moreover, given that the extracellular release of soluble $\mathrm{C}_{\text {org }}$ is typically $10-20 \%$ of the particulate $\mathrm{C}_{\text {org }}$ production by phytoplankton (Baines and Pace, 1991), the role of autochthonous DOC production $\left(0.1-1 \mathrm{mg} . \mathrm{L}^{-1}\right)$ in the thermokarst lakes is negligibly small relative to allochthonous DOC reservoir $\left(10-30 \mathrm{mg} . \mathrm{L}^{-1}\right)$. Therefore, the majority of DOC in Western Siberian thermokarst lakes should be of soil (peat rather than plankton) origin, as also confirmed by specific UV absorbance measurements (Shirokova et al., 2013; Manasypov et al., 2015).

\section{Comparison with other arctic and subarctic lakes}

In contrast to relatively good knowledge of the hydrochemical and physical properties of Western Siberia thermokarst lakes (Walter et al., 2006, 2008; Audry et al., 2011; Karlsson et al., 2012, 2014; Walter Anthony et al., 2012; Manasypov et al., 2014), no information on the phytoplankton population of these lakes is available. Other thermokarst lakes studied all over the world, such as from the Kolyma low land (Walter Anthony et al., 2014), the Lena Delta (Boike et al., 2013), Mackenzie Delta plain (Tank et al., 2009, 2011; Grosse et al., 2013; Walter Anthony and Anthony, 2013), the north of Quebec (Laurion et al., 2010; Negandhi et al., 2014), and NE part of the European Russia (Trifonova, 1998) are more than $2 \mathrm{~m}$ deep and do not freeze solid while exhibiting chemical and thermal stratification of the water column. While the organic-rich thermokarst lakes of eastern Siberia, such as those of the yedoma sites have not yet been studied from the hydrobiological point of view, the Canadian thermokarst and high latitude lakes can serve as a first order analogue of the Siberian thermokarst lakes. This analogy should be considered with caution, however, because the much higher DOC concentrations and lower $\mathrm{pH}$ in the Western Siberia lakes compared with the more oligotrophic Canadian water bodies, render the Western Siberian lakes as quite hostile environments for most phytoplankton, including cyanobacteria and diatoms. 
For example, we observed a decrease of the total cell number and biomass with the decrease of lake water $\mathrm{pH}$ in August (Fig. 6). This effect was most pronounced in summer during the period of active cell growth and highest biodiversity.

The proportion of cyanobacteria in the Western Siberia thermokarst lakes was rather low, never exceeding $20 \%$. The lower proportion of cyanobacteria contrasts their dominance in other subarctic lakes and ponds, and most likely reflects essentially acidic nature of thaw ponds from the peat palsa bog of Western Siberia. Indeed, cyanobacteria represent the major element of the microbiota in Arctic lakes, ponds and streams (Vincent, 2000). Moreover, cyanobacterial species (Synechococcus spp.) were reported to be the dominant plankton in cell number in the lakes and ponds in the Canadian High Arctic (Vézina and Vincent, 1997), and the relative contribution of cyanobacteria compared to that of the Chlorophyta increased from the low to high arctic (Sheath et al., 1996). Picocyanobacteria of $<2 \mu \mathrm{m}$ in diameter are abundant constituents of the phytoplankton in shallow thermokarst ponds in the tundra (Bylot Island) and also in the deep lakes of the Canadian High Arctic. Studies of the foresttundra zone of North America demonstrated the dominance of Synechococcus-like picocyanobacteria (MilotRoy and Vincent, 1994), which are extremely resistant to solar radiation (Laurion and Vincent, 1998) and are highly adapted to the low nutrients of these oligotrophic systems (Bergeron and Vincent, 1997). In addition to the most common genera Synechococcus and Synechocystis, other species, such as colonial Microcystis elabens (Bréb.) Kütz. were identified in the waterbodies on Bylot Island (Vincent, 2000). Finally, neutral pH, eutrophic shallow tundra lakes of the Bolshezemelskaya tundra (Trifonova, 1998) demonstrated the dominance of cyanobacteria $(75 \%$ of the total biomass), contrasting to the pattern of cyanobacteria distribution in the acidic Western Siberia thermokarst lakes in this study.

Among various groups of phytoplankton, diatoms are widely distributed in Northern North America, Fennoscandia, Siberia, the Kola Peninsula and the Novaya Zemlya Island (Lotter et al., 1998). A study of freshwater algae from 279 bodies of water in the Northwest Territories (Sheath and Steinman, 1982) revealed the dominance of diatoms (761 taxa), followed by green algae (481 taxa) and cyanobacteria (173 taxa). In the thermokarst lakes investigated in this study, the diatoms constituted only $7.4 \%$ of the total taxon number. Presumably, the highly acidic and humic nature of the Western Siberia thermokarst lakes render them much less suitable for diatoms compared to the oligotrophic or ultra-oligotrophic lakes of other arctic and subarctic regions. Additionally, the small proportion of diatoms in the studied thermokarst lakes is also consistent with very low concentration of DIC in these lakes, typically $0.5 \pm 0.1 \mathrm{mg} . \mathrm{L}^{-1}$. The DIC is reported to be the most important variable determining the distribution of diatom taxa (Laing and Smol, 2000; Rühland and Smol, 2002). In agreement with previous data of epilithic diatoms in 41 subarctic lakes of northern Finnish Lapland (Albert et al., 2012), the diatom T. flocculosa was among the most common and widely distributed taxa in the Western Siberian thermokarst lakes. It is known that compared with diatom species richness in environments at $\mathrm{pH}$ 4.5-5.0, there are many fewer taxa in environments $\mathrm{pH} 3.5$, suggesting a threshold between $\mathrm{pH} 4.5$ and 3.5 below which many species are unable to maintain a population (DeNicola, 2000). This result aids understanding of the very small number and biomass of diatoms relative to green algae, recorded in the Western Siberian lakes, in comparison with other subarctic aquatic environments of NW Russia, including the Bolshezemelskaya tundra (Getsen, 1985; Trifonova and Petrova, 1994; Trifonova, 1998; Patova, 2014). The North European Arctic habitats are represented by a peat bog palsa permafrost-bearing region that can be considered to be most similar to the thermokarst lakes of Western Siberia, although the $\mathrm{pH}$ of the Bolshezemelskaya tundra permafrost lakes is 1 to 2 units higher and the DOC is a factor of 2 to 3 lower than those of thermokarst lakes studied in this work. These factors may be responsible for elevated phytoplankton parameters of the Bolshezemelskaya tundra relative to Western Siberia thaw ponds (54-158 taxa; $0.3-54 \mathrm{mg}_{\text {wet }} \cdot \mathrm{L}^{-1}$ biomass of the former). Similar number of phytoplankton species was reported for lakes of Finland (Heinonen, 1980) and the Labrador Lakes (Earle and Duthie, 1986): 52-62 and 61, respectively.

Low $\mathrm{pH}$ in small humic lakes of non-permafrost bog zone of Western Siberia (4.0-4.5) also was considered to be responsible for relatively low parameters of phytoplankton during summer time $\left(0.2-0.7\right.$ million cell. $\mathrm{mL}^{-1}$, $0.2-11 \mathrm{mg}_{\text {wet. }} \cdot \mathrm{L}^{-1}$ of biomass) represented by 6-40 taxa with the dominance of Cryptophyta, Euglenophyta and Raphidophyceae (Beliakov et al., 2015). Acidic environment of thaw ponds located in Western Siberia peat bogs limited the development of certain taxons of Desmidiales such as Staurastrum and Staurodesmus, in accord with previous data on Desmidiales diversity in sphagnum eutrophic and mesotrophic peat bogs of non-permafrost zone (Palamar-Mordvintseva, 1982). The lowest $\mathrm{pH}$ favorable for Desmidiales development in thaw ponds determined in this study is in agreement with the range reported for Western Siberia: 5.5-5.8, 5.8-6.0 and 6.1-6.3 for Euastrum, Closterium and Micrasterias, respectively (Kosinskaya, 1960).

The benthic environments of high latitude lakes and ponds were studied by Canadian researchers (e.g., Sheath et al., 1996; Elster et al., 1997; Vérzina and Vincent, 1997). Among the dominant species in Canada's lakes, the mucilage-producing cyanobacteria of the family Oscilatoriaceae, such as Oscillatoria, Phormodium and Schizothrix, are most abundant. Some of these filamentous species are also identified in the water column of the thermokarst lakes of Western Siberia. Note that all of the high latitude filamentous species of Canada exhibit the temperature optima well above their cold ambient temperatures (Tang and Vincent, 1999) and, thus, they are 
likely to be responsive to a climate-warming trend (Tang et al., 1997). This is particularly true for nitrogen-fixing cyanobacteria, such as Nostoc commune, which are also adapted to high solar irradiance (Vincent and Quesada, 1997). It is important to note that the ephemeral nature of many Western Siberia thaw ponds favors significant development of periphytic rather than planktonic form of primary producers, essentially filamentous chlorophytes, as it is known for temperate floodplain lakes (i.e., Pfeiffer et al., 2013). It can be hypothesized that significant fraction of this periphyton is attached to submerged vegetation (moss, grass and dwarf shrubs) although the characterization of these habitats was not attempted.

A survey of the phytoplankton in the lakes, rivers, and temporary pools in the Northwest Territories revealed that Dinobryon bavaricum was the most abundant (Moore, 1978). It was followed in order of decreasing importance by $D$. cylindricum, $D$. sociale and $D$. divergens. The predominant diatoms were Cyclotella glomerata and C. ocellata. Both species reached greatest abundance in the lakes and rivers in the high arctic and were completely absent from temporary pools (Moore, 1978). A study of shallow $(<2 \mathrm{~m})$ thermokarst ponds from the coastal plains of Alaska, NW Territories, which freeze solid every winter demonstrated the dominance of nanoplanktonic flagellates of the Chrysophyceae and Cryptophyceae with cryptomonad Rhodomonas minuta Skuja as the most widespread phytoplankters in tundra ponds (Sheath, 1986). Most species tolerate prolonged freezing by forming resistant vegetative cells with thick walls, plentiful reserves and low molecular weight solutes to lower the freezing point (Sheath et al., 1996). The degree to which these mechanisms of frost resistance can be applied to the phytoplankton communities of the Western Siberia thaw lakes remains unclear. We could not find evidence of the formation of a massive sheath in the cyanobacteria sampled in October, at the beginning of ice formation. However, it can be speculated that the dominance of colony-forming cyanobacteria, such as Nostoc, Microcystis, Aphanocapsa sp., whose cells are assembled within a thick capsule (Fig. ESM-1), may represent such an adaptation mechanism. Note that even green algae (Chlorophyta), normally known to decrease their relative abundance from the low to high Arctic (Sheath et al., 1996), also tend to form multicellular colonies in the shallow thermokarst lakes of Western Siberia discontinuous permafrost zone (Fig ESM-2). The occurrence among cyanobacteria of Microcystis, largely known for its capacity to increase soluble carbohydrate content at low temperature (i.e., Dong et al., 2015), allows the possibility that the water heating in Western Siberia will promote this typically temperate water group of phytoplankton. Because permafrost thaw in Western Siberia leads to appearance of new small $\left(<200 \mathrm{~m}^{2}\right)$ depressions and thaw ponds while decreasing the number of large $\left(>1 \mathrm{~km}^{2}\right)$ thermokarst lakes (Kirpotin et al., 2009, 2011; Polishchuk et al., 2015), detailed study of phytoplankton population in smallest water bodies of frozen peat bogs will allow assessing the first stages of aquatic ecosystem formation.
Finally, study of composition and seasonal dynamics of autotrophic picoplankton, which is especially important in shallow lakes and which requires molecular biological tools (i.e., Vörös et al., 1991; Somogyi et al., 2010), is one of the most timing perspectives of thaw ponds phytoplankton research.

\section{Conclusions}

A first study of the Western Siberia thaw lake plankton composition corroborates the available data from the other subarctic regions while exhibiting distinct features of the acidic, DOC-rich shallow water bodies. Despite the almost dystrophic status of the thermokarst lakes of the palsa peat bog zone (discontinuous permafrost) in Western Siberia, the phytoplankton biodiversity of these small water bodies is high; the total number of 134 species is well within the range of the most typical number of lake phytoplankton (50-150, Willen, 1979). The dominant components of the algae are benthic forms, similar to Canadian lakes. In October, we observed a decrease of the biodiversity and an increase of Chrysophyceae (golden algae) and Cryptophyta, whereas in summer, we observed the highest biomass and cell number, potentially indicating the possibility of bloom conditions. In accord with other permafrost-affected Eurasian lakes (Trifonova, 1998), the highest species diversity (106 taxa) is observed in the lakes with highest biomass $\left(10-30 \mathrm{mg}_{\text {wet }} \cdot \mathrm{L}^{-1}\right)$.

The dominant components of the phytoplankton in the acidic, humic thermokarst lakes of Western Siberia are charales, green algae, cyanobacteria, Dinophyta, diatoms and golden algae, constituting 37, 20, 13, 8.1, 7.4 and 6.7\% of all taxa, respectively. No direct link of chemical (DOC, DIC) parameters of the lakes with the total phytoplankton biomass and biodiversity could be established, although the lake having the highest $\mathrm{pH}$ and DIC exhibited the highest biomass and biodiversity. Fe and $\mathrm{Si}$ were identified as other potential nutrients for diatoms and green algae using a PCA approach. Both the cell number and phytoplankton biomass decreased with the lake size and $\mathrm{pH}$ increase, a trend that was especially pronounced during biological summer (August). This trend is consistent with the lake maturation with the lake size increase, accompanied by bacterioplankton and nutrient decrease. The difference in phytoplankton parameters for lakes of different size disappeared in June, when the hydrochemical contrast between lakes was also minimal. The dominance of colony-forming cyanobacteria (Microcystis, Aphanocapsa, Merismopedia, Nostoc), having thick capsules, may represent an adaptation mechanism to the full freezing of the Western Siberian thermokarst lakes in winter.

Acknowledgements. We acknowledge full support from an RSF grant no. 15-17-10009 "Evolution of thermokarst lake ecosystem in the context of climate change". OP and RM also acknowledge partial support from BIO-GEO-CLIM grant from the Ministry of Education and Science of the Russian Federation and Tomsk State University (no 14.B25.31.0001). 


\section{REFERENCES}

Albert R.-L., Korhola A. and Sorvari S., 2012. Analysis of factors controlling epilithic diatom community compositions in subarctic lakes of Finnish Lapland. Adv. Limn., 62, 125-151.

Audry S., Pokrovsky O.S., Shirokova L.S., Kirpotin S.N. and Dupré B., 2011. Organic matter mineralization and trace element post-depositional redistribution in Western Siberia thermokarst lake sediments. Biogeosciences, 8, 3341-3358.

Baines S.B. and Pace M.L., 1991. The production of dissolved organic matter by phytoplankton and its importance to bacteria: patterns across marine and freshwater systems. Limnol. Oceanog., 36, 1078-1090.

Barinova S.S., Medvedeva L.A. and Anisimova O.V., 2006. Biodiversity of Algae - Indicators of the Environment, Tell-Aviv Publ. House, Tel-Aviv, Israel, 356 p.

Beliakov V.P., Stanislavskaya E.V. and Kapustina L.L., 2015. Estimation of ecological state of some small lakes and rivers of Western Siberia by quantitative characteristics of phyto-, bacterioplankton and zoobenthos. In: Ecological Status of Northern Continental Reservoirs, Proc. Int. Symp., Archangelsk, Russia, 2005, 21-25 June, Saint-Petersburg, 89-96.

Bergeron M. and Vincent W.F., 1997. Microbial food web responses to phosphorus and solar UV radiation in a subarctic lake. Aquat. Microbiol. Ecol., 12, 129-249.

Boike J., Kattenstroth B., Abramova K., Bornemann N., Chetverova A., Fedorova I., Fröb K., Grigoriev M., Grüber M., Kutzbach L., Langer M., Minke M., Muster S., Piel K., Pfeiffer E.-M., Stoof G., Westermann S., Wischnewski K., Wille C. and Hubberten H.-W., 2013. Baseline characteristics of climate, permafrost and land cover from a new permafrost observatory in the Lena River Delta, Siberia (1998-2011). Biogeosciences, 10, 2105-2128.

Bonilla S., Villeneuve V. and Vincent W.F., 2005. Benthic and planktonic algal communities in a High Arctic Lake: pigment structure and contrasting responses to nutrient enrichment. J. Phycol., 41, 1120-1130.

Coesèl P. and Meesters K., 2007. Desmids of the Lowlands: Mesotaeniaceae and Desmidiaceae of the European Lowlands, KNNV Publishing, The Netherlands.

Comte J., Monier A., Crevecoeur S., Lovejoy C. and Vincent W.F., 2015. Bacterial biogeography of permafrost thaw ponds across the changing northern landscape. Ecography, 38, 1-10, doi: 10.1111/ecog.01667.

Craig S.R., 1987. The distribution and contribution of picoplankton to deep photosynthetic layers in some meromictic lakes. Acta Academ. Aboensis, 47, 55-81.

DeNicola D.M., 2000. A review of diatoms found in highly acidic environments. Hydrobiologia, 433, 111-122.

Dong J., Zhou W., Song L. and Li G., 2015. Responses of phytoplankton functional groups to simulated winter warming. Ann. Limnol. - Int. J. Lim., 51, 199-210.

Douglas M.S.V. and Smol J.P., 1994. Limnology of high arctic ponds (Cape Herschel, Ellesmere Island, N.W.T.). Arch. Hydrobiol., 131, 401-434.

Douglas M.S.V. and Smol J.P., 1995. Periphytic diatom assemblages from High Arctic ponds. J. Phycol., 31, 60-69.

Dugan H.A., Lamoureaux S.F., Lewis T. and Lafrenière M.J., 2012. The impact of permafrost disturbances and sediment loading on the limnological characteristics of two High Arctic lakes. Permafrost Periglacial Proc., 23, 119-126.

Earle I.C. and Duthie H.C., 1986. Analysis of phytoplankton composition of 95 Labrador Lakes with special reference to natural and anthropogenic acidification. Can. J. Fish. Aquat. Sci., 43, 1804-1811.

Elster J., Svoboda J., Kormarek J. and Marvan P., 1997. Algal and cyanoprocaryote communities in a glacial stream, Svedrup Pass, $79^{\circ} \mathrm{N}$, Central Ellesmere Island, Canada. Arch. Hydrobiol. Suppl. Algol. Stud., 85, 57-93.

Forsström L., Sorvari S., Korhola A., and Rautio M., 2005. Seasonality of phytoplankton in subarctic Lake Saanajärvi in NW Finnish Lapland. Polar Biol., 28, 846-861.

Forsström L., Sorvari S., Rautio M., Sonninen E. and Korhola A., 2007. Changes in physical and chemical limnology and plankton during the spring melt period in a subarctic lake. Int. Rev. Hydrobiol., 92, 301-325.

Getsen M.V., 1985. Algae in the Ecosystems of Far North (example of Bolshezemelskaya Tundra), Leningrad, Nauka, 165 p. (in Russian).

Grosse G., Jones B. and Arp C., 2013. Thermokarst lakes, drainage, and drained basins. In: Shroder J. (Editor in Chief), Giardino R., Harbor J. (eds.), Treatise on Geomorphology, Vol. 8, Academic Press, San Diego, CA, Glacial and Periglacial Geomorphology, 325-353.

Guseva K.A., 1959. Methods of phytoplankton counting. Trudy. Inst. Biol. Vodochr., 2, 44-51 (In Russian).

Hay M.B., Michelutti N. and Smol J.P., 2000. Ecological patterns of diatom assemblages from Mackenzie Delta lakes, Northwest Territories, Canada. Canad. J. Bot., 78, 19-33.

Heinonen P., 1980. Quality and composition of phytoplankton in finnish inland waters. Publ. Water Res. Inst. Helsinki, 37, $1-91$.

Jasser L. and Arvola L., 2003. Potential effects of abiotic factors on the abundance of autotrophic picoplankton in four boreal lakes. J. Plankton Res., 25, 873-883.

Karlsson J.M., Lyon S.W. and Destouni C., 2012. Thermokast lake, hydrological flow and water balance indicators of permafrost change in Western Siberia. J. Hydrol., 464-465, 459-466.

Karlsson J.M., Lyon S.W. and Destouni G., 2014. Temporal behavior of lake size-distribution in a thawing permafrost landscape in Northwestern Siberia. Rem. Sens., 6, 621-636.

Kirpotin S., Polishchuk Y. and Bryksina N., 2009. Abrupt changes of thermokarst lakes in Western Siberia: impacts of climatic warming on permafrost melting. Int. J. Environ. Stud., 66, 423-431.

Kirpotin S., Polishchuk Y., Bryksina N., Sugaipova A., Kouraev A., Zakharova E., Pokrovsky O.S., Shirokova L., Kolmakova M., Manassypov R. and Dupré B., 2011. West Siberian palsa peatlands: distribution, typology, cyclic development, present day climate-driven changes, seasonal hydrology and impact on $\mathrm{CO}_{2}$ cycle. Int. J. Environ. Stud., 68, 603-623.

Kokelj S.V., Jenkins R.E., Milburn D., Burn C.R. and Snow N., 2005. The influence of thermokarst disturbance on the water quality of small upland lakes, Mackenzie Delta Region, Northwest Territories, Canada. Permafrost Periglacial Proc., 16, 343-353.

Kokelj S.V., Zajdlik B. and Thompson M.S., 2009. The impacts of thawing permafrost on the chemistry of lakes across 
the subarctic boreal-tundra transition, Mackenzie Delta Region, Canada. Permafrost Periglacial Proc., 20, 185-199.

Kosinskaya E.K., 1960. Desmid Algae. Izd-vo AN USSR, Moscow-Leningrad Publ. House, Moscow, USSR, 706 p. (in Russian).

Laing T. and Smol J.P., 2000. Factors influencing diatom distribution in circumpolar treeline lakes of northern Russia. J. Phycol., 36, 1035-1048.

Laurion I. and Vincent W.F., 1998. Cell size versus taxonometric composition as determinants of UV sensitivity in natural phytoplankton communities. Limnol. Oceanogr., 43, 1774-1779.

Laurion I., Vincent W.F., MacIntyre S., Retamal L., Dupont C., Francus P. and Pienitz R., 2010. Variability in greenhouse gas emissions from permafrost thaw ponds. Limnol. Oceanogr., 55, 115-133.

Levine M.A. and Whalen S.C., 2001. Nutrient limitation of phytoplankton production in Alaskan Arctic foothill lakes. Hydrobiologia, 455, 189-201.

Lotter A.F., Pienitz R. and Schmidt R., 1998. Diatoms as indicators of environmental change near Arctic and treeline. In: Stoermer E.F. and Smol J.P. (eds.). The Diatoms: Applications to the Environment and Earth Sciences, Cambridge University Press, Cambridge.

Makarova I.V. and Pichkily L.O., 1970. On some questions of the method of biomass of phytoplankton calculation. Bot. J. (Botanicheskii Zhurnal), 55, 1488-1494.

Manasypov R.M., Pokrovsky O.S., Kirpotin S.N. and Shirokova L.S., 2014. Thermokarst lakes waters across permafrost zones of Western Siberia. Cryosphere, 8, 1177-1193.

Manasypov R.M., Vorobyev S.N., Loiko S.V., Krivtzov I.V., Shirokova L.S., Shevchenko V.P., Kirpotin S.N., Kulizhsky S.P., Kolesnichenko L.G., Zemtsov V.A., Sinkinov V.V. and Pokrovsky O.S., 2015. Seasonal dynamics of thermokarst lake chemical composition in discontinuous permafrost zone of Western Siberia. Biogeosciences, 12, 3009-3028.

Milot-Roy V. and Vincent W.F., 1994. UV radiation effects on photosynthesis: the imp,ortance of near-surface thermoclines in a subarctic lake. Arch. Hydrobiol. Beih., 43, 171-184.

Moore J.W., 1978. Distribution and abundance of phytoplankton in 153 lakes, rivers, and pools in the Northwest Territories. Can. J. Bot., 56, 1765-1773.

Mozés A., Présing M. and Vörös L., 2006. Seasonal dynamics of picocyanobacteria and picoeukaryotes in a large shallow lake (Lake Balaton, Hungary). Int. Rev. Hydrobiol., 91, 38-50.

Negandhi K., Laurion I., Whiticar M.J., Galand P.E., Xu X. and Lovejoy C., 2013. Small thaw ponds: an accounted source of methane in the Canadian high Arctic. PLoS ONE, 8, e78204.

Odum E.P., 1971. Fundamentals of Ecology, Saunders, Philadelphia.

Palamar-Mordvintseva G.M., 1982. Green algae. Class Conjugates. Desmidiales, Nauka, Leningrad, 620 p. (in Russian).

Patova E.N., 2014. Bloom-forming cyanoprokaryotes in Kharbeyskie Lakes of Bolshezemelskaya Tundra. J. Siber. Fed. Univ., Biology, 3, 282-290.

Pfeiffer T.Z., Mihaljevic M., Stevic F. and Spoljaric D., 2013. Periphytic algae colonization driven by variable environmental components in a temperate floodplain lake. Ann. Limnol. - Int. J. Lim., 49, 179-190.
Pick F.R. and Agbeti D.M., 1991. The seasonal dynamic and composition of photosynthetic picoplankton communities in temperate lakes in Ontario, Canada. Int. Rev. Hydrobiol., 76, 565-580.

Pokrovsky O.S., Shirokova L.S., Kirpotin S.N., Audry S., Viers J. and Dupré B., 2011. Effect of permafrost thawing on the organic carbon and metal speciation in thermokarst lakes of western Siberia. Biogeosciences, 8, 565-583.

Pokrovsky O.S., Shirokova L.S., Kirpotin S.N., Kulizhsky S.P. and Vorobiev S.N., 2013. Impact of western Siberia heat wave 2012 on greenhouse gases and trace metal concentration in thaw lakes of discontinuous permafrost zone. Biogeosciences, 10, 5349-5365.

Pokrovsky O.S., Shirokova L.S. and Kirpotin S.N., 2014. Biogeochemistry of Thermokarst Lakes of Western Siberia, Nova Science Publishers, Inc., New York, 176 p. ISBN 978-1-62948-567-6.

Polishchuk Y.M., Bryksina N.A. and Polishchuk V.Y., 2015. Remote analysis of changes in the number of small thermokarst lakes and their distribution with respect to their sizes in the cryolithozone of Western Siberia. Izvestiya, Atmosph. Ocean. Phys., 51, 999-1006.

Rautio M., Dufresne F., Laurion I., Bonilla S., Vincent W.F. and Christoffersen K.S., 2011. Shallow freshwater ecosystems of the circumpolar Arctic. Ecoscience, 18, 205-222.

Rühland K.M. and Smol J.P., 2002. Freshwater diatoms from the Canadian Arctic treeline and development of paleolimnological inference models. J. Phycol., 38, 249-264.

Sheath R.G., 1986. Seasonality of phytoplankton in northern tundra ponds. Hydrobiologia, 138, 75-83.

Sheath R.G. and Steinman A.D., 1982. A checklist of freshwater algae of the Northwest Territories, Canada. Can. J. Bot., 60, 1964-1997.

Sheath R.G., Vis M.L., Hambrook J.A. and Cole K.M., 1996. Tundra stream macroalgae of North America: composition, distribution and physiological adaptations. Hydrobiologia, $336,67-82$.

Shirokova L.S., Pokrovsky O.S., Kirpotin S.N. and Dupré B., 2009. Heterotrophic bacterio-plankton in thawed lakes of northern part of Western Siberia controls the $\mathrm{CO}_{2}$ flux to the atmosphere. Int. J. Environ. Stud., 66, 433-445.

Shirokova L.S., Pokrovsky O.S., Kirpotin S.N., Desmukh C., Pokrovsky B.G., Audry S. and Viers J., 2013. Biogeochemistry of organic carbon, $\mathrm{CO}_{2}, \mathrm{CH}_{4}$, and trace elements in thermokarst water bodies in discontinuous permafrost zones of Western Siberia. Biogeochemistry, 113, 573-593.

Sladecek V., 1973. System of water quality from the biological point of view. Ergebn. Limnol. - H. 7. - Arsh. Hydrobiol. Bienheft., 7, 1-218.

Somogyi B., Felföldi T., Dinka M. and Vörös L., 2010. Periodic picophytoplankton predominance in a large, shallow alkaline lake (Lake Fertö, Neusiedlersee). Ann. Limnol. - Int. J. Lim., 46, 9-19.

Stockner J.G. and Shortreed K.S., 1991. Autotrophic picoplankton: community composition abundance and distribution across a gradient of oligotrophic British Columbia and Yukon Territory lakes. Int. Rev. Hydrobiol., 76, 585-601.

Tang E.Y. and Vincent W.F., 1999. Strategies of temperature acclimation by two mat-forming cyanobacteria 
from contrasting polar environments. New Phytol., 142, 315-323.

Tang E.Y., Tremblay R. and Vincent W.F., 1997. Cyanobacterial dominance of polar freshwater ecosystems: are high latitude mat-formers adapted to the low temperature environment? J. Phycol., 33, 171-181.

Tank S.E., Esslein R.H.H. and Esack L.F.W.L., 2009. Northern delta lakes as summertime $\mathrm{CO}_{2}$ absorbers within the arctic landscape. Ecosystems, 12, 144-157.

Tank S.E., Lesack L.F.W., Gareis J.A.L., Osburn C.L. and Hesslein R.H., 2011. Multiple tracers demonstrate distinct sources of dissolved organic matter to lakes of the Mackenzie Delta, western Canadian Arctic. Limnol. Oceanogr., 56, 1297-1309.

Trifonova I.S., 1998. Phytoplankton composition and biomass structure in relation to trophic gradient in some temperate and subarctic lakes of northwestern Russia and the Prebaltic. Hydrobiologia, 369/370, 99-108.

Trifonova I.S. and Petrova A.L., 1994. Structure and dynamics of phytoplankton biomass. In: Drabkova, V.G. and Trifonova I.S. (eds.), Peculiarities of Ecosystems of Lakes of the North (Case Study of Bolshezemelskaya Tundra Lakes), Nauka, St. Petersbourg, 80-109 (in Russian).

Vérzina S. and Vincent W.F., 1997. Arctic cyanobacteria and limnologicla properties of their environment: Bylot Island, Northwest Territories, Canada $\left(73^{\circ} \mathrm{N}, 80^{\circ} \mathrm{W}\right)$. Polar Biol., 17, 523-534.

Vincent W.F., 2000. Cyanobacterial dominance in the polar regions. In: Whitton, B. and Potts M. (eds.), Ecology of the Cyanobacteria: their Diversity in Space and Time, Kluwers Academic Press, Netherlands, pp. 321-340.

Vincent W.F. and Quesada A., 1997. Microbial niches in the polar environment and the escape from UV radiation in non-marine habitats. In: Battaglia B., Valencia J. and Walton D. (eds.) Antarctic Communities: Species, Structure and Survival, Cambridge University Press, Cambridge, pp. 388-395.
Vörös L., Gulyas P. and Németh J., 1991. Occurrence, dynamics and production of picoplankton in Hungarian shallow lakes. Int. Rev. Ges. Hydrobiol., 76, 617-629.

Walter K.M., Zimov S.A., Chanton J.P., Verbyla D. and Chapin F.S. III, 2006. Methane bubbling from Siberian thaw lakes as a positive feedback to climate warming. Nature, 443, 71-75.

Walter K.M., Chanton J.P., Chapin F.S. III, Schuur E.A.G. and Zimov S.A., 2008. Methane production and bubble emissions from arctic lakes: isotopic implications for source pathways and ages. J. Geophys. Res., 113, G00A08.

Walter Anthony K.M. and Anthony P., 2013. Constraining spatial variability of methane ebullition in thermokarst lakes using point-process models. J. Geophys. Res., 118, 1015-1034.

Walter Anthony K.M., Anthony P., Grosse G. and Chanton J., 2012. Geologic methane seeps along boundaries of Arctic permafrost thaw and melting glaciers. Nat. Geosci., 5, 419-426.

Walter Anthony K.M., Zimov S.A., Grosse G., Jones M.C., Anthony P.M., Chapin F.S. III, Finlay J.C., Mack M.C., Davydov S., Frenzel P. and Frolking S., 2014. A shift of thermokarst lakes from carbon sources to sinks during the Holocene epoch. Nature, 511, 452-456.

Willén E., 1979. Water quality and phytoplankton in two large Swedish lakes. Acta Botan. Fennica, 110, 81-85.

Yeghicheyan D., Bossy C., Bouhnik Le Coz M., Douchet C., Granier G., Heimburger A., Lacan F., Lanzanova A., Rousseau T.C.C., Seidel J.-L., Tharaud M., Candaudap F., Chmeleff J., Cloquet C., Delpoux S., Labatut M., Losno R., Pradoux C., Sivry Y. and Sonke J. E. (2013) A Compilation of Silicon, Rare Earth Element and Twenty-One other Trace Element Concentrations in the Natural River Water Reference Material SLRS-5 (NRC-CNRC). Geostandards and Geoanalytical Research, 37, 449-467. doi: 10.1111/j.1751908X.2013.00232.x. 